\title{
Hubungan tingkat pengetahuan PHBS tatanan RT dengan PHBS warga di bantaran Sungai Kahayan Palangka Raya tahun 2016
}

\author{
T. Widodo ${ }^{1 *}$, F. D. Alexandra ${ }^{1}$ \\ ${ }^{1}$ Fakultas Kedokteran, Universitas Palangka Raya, Kalimantan Tengah, Indonesia
}

\begin{abstract}
Abstrak
Perilaku Hidup Bersih dan Sehat (PHBS) merupakan perilaku sehat yang dilakukan atas kesadaran, sehingga seseorang dapat menolong dirinya sendiri di bidang kesehatan. Penelitian ini mengambil 3 indikator dalam PHBS yaitu perilaku menggunakan jamban sehat, cuci tangan pakai sabun (CTPS) dan air mengalir, serta pemberian ASI (Air Susu Ibu) eksklusif. Data di Kota Palangka Raya menunjukkan persentase perilaku warga yang menggunakan jamban sehat sebesar $54 \%$, perilaku cuci tangan pakai sabun $14 \%$, dan perilaku pemberian ASI eksklusif 39,3\%. Penelitian bertujuan menganalisis hubungan tingkat pengetahuan PHBS tatanan RT dengan PHBS (menggunakan jamban sehat, CTPS dan pemberian ASI eksklusif) warga di bantaran Sungai Kahayan wilayah kerja Puskesmas Pahandut. Jenis penelitian observasional dengan pendekatan cross sectional. Sebanyak 95 responden yang memiliki balita di wilayah kerja Puskesmas Pahandut dipilih menggunakan teknik simple random sampling dan dianalisis dengan Chi Square $(\alpha=0,05)$. Sebanyak 54 responden memiliki tingkat pengetahuan PHBS yang baik, 67 responden berperilaku menggunakan jamban sehat dengan baik, 69 responden berperilaku CTPS dengan baik dan 53 responden memberikan ASI eksklusif . Semua p value $=0.00$. Terdapat hubungan tingkat pengetahuan PHBS tatanan RT dengan PHBS (menggunakan Jamban Sehat, CTPS dan Pemberian ASI eksklusif) warga di Bantaran Sungai Kahayan wilayah kerja Puskesmas Pahandut Palangka Raya Tahun 2016.
\end{abstract}

Kata kunci: PHBS, tingkat pengetahuan PHBS, jamban sehat, CTPS, ASI eksklusif

\begin{abstract}
.
Clean and Healthy Living Behavior (PHBS) is a healthy behavior carried out on the consciousness, so that someone can help himself in the field of health. This study took 3 indicators in PHBS, namely the behavior of using healthy latrines, wash hands with soap (CTPS) and running water, and exclusive breastfeeding. Data on Palangka Raya City showed a percentage of behavior of resident who used healthy latrine is $54 \%$, hand washing with soap (CTPS) $14 \%$ and exclusive breastfeeding 39.3\%. Research aimed at analyzing the relationship between the knowledge level of PHBS RT and PHBS (using healthy latrines, CTPS and exclusive breastfeeding) at residents in the Kahayan River basin working area of Puskesmas Pahandut. Observational research applied cross sectional approach. As many as 95 respondents who have toddlers in the work area of Puskesmas Pahandut selected using simple random sampling technique and analyzed with Chi Square ( $\alpha=0.05)$. A total of 54 respondents had a good level of PHBS knowledge, 67 respondents had good behavior using good healthy latrine, 69 respondents had good CTPS behavior and 53 respondents had exclusive breastfeeding behaviour. All $p$ value $=0.00$. There was a relationship between the knowledge level of PHBS RT and PHBS (Using Healthy Jamban, CTPS and Exclusive Breastfeeding) at residents in the Kahayan River Basin work area of Puskesmas Pahandut Palangka Raya year 2016.
\end{abstract}

Keywords: PHBS, knowledge level of PHBS, healthy latrines, CTPS, exclusive breastfeeding

\section{PENDAHULUAN}

Perwujudan dari Perilaku Hidup Bersih dan Sehat (PHBS) adalah dengan adanya keberdayaan masyarakat yang sadar, mau dan mampu melakukan semua perilaku kesehatan, sehingga anggota keluarga atau keluarga dapat menolong dirinya sendiri di bidang kesehatan, serta berperan aktif dalam kegiatankegiatan kesehatan di masyarakat (Proverawati dan Rahmawati 2012). Pendekatan untuk melakukan PHBS dengan melalui lima tatanan yaitu PHBS di: rumah tangga, sekolah, tempat kerja, institusi kesehatan dan tempat umum. Salah satu upaya untuk menggerakkan dan memberdayakan anggota rumah

\footnotetext{
${ }^{*}$ Korespondensi Penulis

Email : widodo.ppk08@gmail.com
} 
tangga atau keluarga untuk berperilaku hidup bersih dan sehat adalah dengan PHBS di rumah tangga (Kemenkes RI 2010).

Rata-rata persentase PHBS nasional berdasarkan indeks pembangunan kesehatan masyarakat 2010, hanya 35,68\% dari seluruh warga Indonesia yang ber-PHBS. Data survei Profil Kesehatan Provinsi Kalimantan Tengah tahun 2014 cakupan rumah tangga yang ber-PHBS masih rendah yaitu dari hasil pemantauan rumah tangga pada tahun 2014, dari 49.007 rumah tangga di Kota Palangka Raya, terpilih secara acak 2.431 rumah tangga, dengan jumlah 772 rumah tangga $(31,8 \%)$ yang telah melaksanakan PHBS. Kesenjangan pencapaian rumah tangga yang ber-PHBS masih cukup besar jika dibandingkan dengan target sebesar 80\% (Dinkes Provinsi Kalimantan Tengah 2014).

Berdasarkan hasil Environmental Health Risk Assessment (EHRA) dapat diketahui bahwa di Kota Palangka Raya persentase tempat buang air besar menggunakan jamban pribadi sebesar 54\%, MCK/WC umum 16\% responden, buang air besar ke sungai 9\%, ke "WC helikopter" sebesar 7\%, ke selokan/parit $5 \%$, ke kebun/pekarangan 3\%, sebesar 3\% ke lubang galian dan lainnya. Perilaku responden yang melakukan cuci tangan pakai sabun (CTPS) sebesar 14\%, sedangkan yang tidak melakukan CTPS sebesar 86\% (EHRA 2014).

Data dari Profil Kesehatan Provinsi Kalimantan Tengah Tahun 2012 menunjukkan, cakupan pemberian ASI eksklusif di Kalimantan Tengah pada tahun 2012 sebesar 22,8\% (Dinkes Provinsi Kalimantan Tengah 2014). Cakupan pemberian ASI eksklusif di Kota Palangka Raya berdasarkan Profil Kesehatan Kota Palangka Raya Tahun 2014 mencapai 39,3\% (Dinkes Kota Palangka Raya 2014). Persentase tersebut masih jauh dari target (80\%) yang telah dicanangkan oleh Kemenkes RI per tahun 2014 (Kemenkes RI 2013).

Perilaku kesehatan, dapat terbentuk bila terdapat dukungan dari beberapa faktor perilaku seperti dikutip dari teori Lawrence Green (1980). Pertama, faktor predisposisi yaitu faktor yang memberikan kemudahan seseorang untuk bertindak, meliputi tingkat pengetahuan, pendidikan, sikap, keyakinan, nilainilai, usia. Kedua, faktor pemungkin adalah faktor yang memungkinkan atau memfasilitasi perilaku atau tindakan, yang meliputi pekerjaan, pendapatan, ketersediaan sarana, fasilitas yang baik. Ketiga, faktor penguat adalah faktor yang mendorong terjadinya perilaku, yang meliputi penyuluhan oleh petugas kesehatan termasuk tokoh adat dan agama. Green (1980) menjelaskan bahwa tingkat pengetahuan adalah domain yang sangat penting dalam membentuk tindakan seseorang. Seseorang berperilaku sesuai dengan pengetahuannya dengan sadar yang ditimbulkan dari pengetahuan yang dimilikinya (Purwaningrum 2015).

Dari uraian diatas peneliti tertarik untuk mengetahui ada atau tidaknya hubungan antara tingkat pengetahuan perilaku hidup bersih dan sehat (PHBS) 
tatanan rumah tangga dengan PHBS (menggunakan jamban sehat, CTPS, dan ASI eksklusif) warga di bantaran Sungai Kahayan wilayah kerja Puskesmas Pahandut Palangka Raya.

\section{METODOLOGI}

\subsection{Lokasi kajian dan waktu penelitian}

Metode dalam penelitian ini menggunakan metode analitik observasional dengan pendekatan cross sectional, yang bertujuan mengetahui tingkat pengetahuan Perilaku Hidup Bersih dan Sehat (PHBS) tatanan Rumah Tangga dengan PHBS (menggunakan jamban sehat, CTPS dan ASI eksklusif) pada warga di Bantaran Sungai Kahayan wilayah kerja Puskesmas Pahandut Palangka Raya. Tempat penelitian ini dilakukan di daerah bantaran Sungai Kahayan wilayah kerja Puskesmas Pahandut Kota Palangka Raya dan dilaksanakan pada bulan Agustus-Oktober 2016.

\subsection{Prosedur analisis data}

Data diolah melalui tahapan editing, coding, data entry, cleaning, dan tabulating. Data yang telah dikumpulkan dianalisis dengan menggunakan program pengolah data. Analisis data dilakukan dua tahap yaitu Analisis Univariabel untuk mengetahui distribusi frekuensi dan proporsi setiap variabel baik bebas dan terikat, penyajian data analisis univariabel ini dalam bentuk tabel. Untuk mengetahui kemaknaan hubungan antara variabel bebas dan variabel terikat digunakan analisis bivariabel. Uji yang dipakai pada penelitian ini adalah uji chi square $(\alpha=0,05)$ menggunakan bantuan program pengolah data.

\section{HASIL DAN PEMBAHASAN}

\subsection{Hasil penelitian}

Tempat penelitian ini di wilayah kerja Puskesmas Pahandut, Palangka Raya. Wilayah kerja Puskesmas Pahandut memiliki luas 25 km, yang termasuk dalam wilayah Kecamatan Pahandut, terletak di Kelurahan Pahandut dengan luas wilayah 9,50 km², di Kelurahan Pahandut seberang 44,00 $\mathrm{km}^{2}$ dan Kelurahan Tumbang Rungan 23,00 km². Puskesmas ini memiliki 4 Puskesmas Pembantu (Pustu) yaitu Pustu Murjani, Pustu Rindang Binua, Pustu Tumbang Rungan, dan Pustu Pahandut Seberang. Jumlah penduduk di Kecamatan Pahandut sekitar 28.456 jiwa dengan jumlah kepala keluarga sekitar $6675 \mathrm{KK}$.

Responden dalam penelitian ini pada awalnya berdasarkan hitungan besar sampel adalah 105. Seiring dengan berjalannya kegiatan karena ada yang drop out respondent menjadi 95 orang, yaitu ibu rumah tangga yang mempunyai balita, dengan usia dari 19-50 tahun berlatar belakang pendidikan terakhir sebagian besar adalah SD dan SLTP. 


\subsubsection{Analisis Univariabel}

Berdasarkan Tabel 1, usia responden paling banyak 26-35 tahun (dari 95 responden) yakni berjumlah 34 orang $(35,8 \%)$. Usia tersebut dikategorikan sebagai masa dewasa awal. Responden yang berjumlah paling sedikit berasal dari usia 46-50 tahun (masa lansia awal) yakni sebanyak 8 orang $(8,4 \%)$.

Tabel 1. Distribusi responden berdasarkan usia dan pendidikan.

\begin{tabular}{lcr}
\hline Variabel & $\mathrm{N}$ & Persentase (\%) \\
\hline Usia & & \\
\hline $19-25$ tahun & 28 & 29,5 \\
$26-35$ tahun & 34 & 35,8 \\
$36-45$ tahun & 25 & 26,3 \\
$46-50$ tahu & 8 & 8,4 \\
\hline Pendidikan & & 47,4 \\
\hline SD & 45 & 38,9 \\
SLTP/SMP & 37 & 12,6 \\
SLTA/SMA & 12 & 1,1 \\
Perguruan Tinggi & 1 & \\
\hline
\end{tabular}

Tabel 2. Distribusi responden berdasarkan tingkat pengetahuan PHBS pada warga di bantaran Sungai Kahayan wilayah kerja Puskesmas Pahandut Palangka Raya.

\begin{tabular}{ccc}
\hline Tingkat Pengetahuan PHBS & N & Persentase (\%) \\
\hline Baik & 54 & 56,8 \\
Kurang & 41 & 33,2 \\
\hline
\end{tabular}

Tabel 2 menunjukkan bahwa responden dengan tingkat pengetahuan PHBS baik sebanyak 54 orang (56,8\%) dan kurang sebanyak 41 orang $(33,2 \%)$.

Tabel 3. Distribusi responden berdasarkan perilaku menggunakan jamban sehat pada warga di bantaran Sungai Kahayan wilayah kerja Puskesmas Pahandut Palangka Raya tahun 2016.

\begin{tabular}{ccc}
\hline Perilaku Menggunakan Jamban Sehat & N & Persentase (\%) \\
\hline Baik & 67 & 70,5 \\
Kurang & 28 & 29,5 \\
\hline
\end{tabular}

Berdasarkan Tabel 3 diketahui bahwa 95 responden yang berperilaku menggunakan jamban sehat dengan baik sebanyak 67 orang $(70,5 \%)$ dan yang berperilaku kurang sebanyak 28 orang (29,5\%).

Tabel 4. Distribusi frekuensi perilaku mencuci tangan (CTPS) pada warga di bantaran Sungai Kahayan wilayah kerja Puskesmas Pahandut Palangka Raya tahun 2016.

\begin{tabular}{ccc}
\hline Perilaku CTPS & N & Persentase (\%) \\
\hline Baik & 69 & 72,6 \\
Kurang & 26 & 27,4 \\
\hline
\end{tabular}


Tabel 4 menunjukkan bahwa responden yang memiliki perilaku baik dalam mencuci tangan sebanyak 69 orang $(72,8 \%)$, sedangkan yang kurang sebanyak 26 orang $(27,2 \%)$.

Tabel 5. Distribusi frekuensi berdasarkan pemberian ASI eksklusif warga di bantaran Sungai Kahayan wilayah kerja Puskesmas Pahandut Palangka Raya tahun 2016.

\begin{tabular}{ccc}
\hline Pemberian ASI & N & Persentase (\%) \\
\hline Eksklusif & 53 & 55,79 \\
Non Eksklusif & 42 & 44,21 \\
\hline
\end{tabular}

Berdasarkan Tabel 5 dapat dilihat bahwa 53 (55,79\%) orang responden memberikan ASI eksklusif dan $42(44,21 \%)$ orang responden tidak memberikan ASI eksklusif.

\subsubsection{Analisis Bivariat}

Berdasarkan Tabel 6 diketahui bahwa responden yang berpengetahuan PHBS dan memiliki perilaku menggunakan jamban sehat yang baik sebanyak 47 orang (87\%), sedangkan yang berpengetahuan PHBS dan memiliki perilaku menggunakan jamban sehat yang kurang sebanyak 21 orang $(51,2 \%)$. Hubungan antara tingkat pengetahuan PHBS dengan perilaku menggunakan jamban sehat ditunjukkan oleh $p$ value $<0,05(0,007)$.

Tabel 6. Hubungan tingkat pengetahuan PHBS dengan perilaku menggunakan jamban sehat pada warga di bantaran Sungai Kahayan daerah kerja Puskesmas Pahandut Palangka Raya tahun 2016.

\begin{tabular}{|c|c|c|c|}
\hline \multirow[b]{2}{*}{ Tk. Pengetahuan PHBS } & \multicolumn{2}{|c|}{ Perilaku Menggunakan Jamban Sehat } & \multirow[b]{2}{*}{ Pvalue } \\
\hline & $\begin{array}{c}\text { Baik } \\
\mathrm{N}(\%)\end{array}$ & $\begin{array}{c}\text { Kurang } \\
\mathrm{N}(\%)\end{array}$ & \\
\hline $\begin{array}{c}\text { Baik } \\
\text { Kurang } \\
\end{array}$ & $\begin{array}{c}47(87 \%) \\
20(48,8 \%) \\
\end{array}$ & $\begin{array}{c}7(13 \%) \\
21(51,2 \%) \\
\end{array}$ & 0,007 \\
\hline
\end{tabular}

Tabel 7. Hubungan tingkat pengetahuan PHBS dengan perilaku CTPS pada warga di bantaran Sungai Kahayan daerah kerja Puskesmas Pahandut Palangka Raya tahun 2016.

\begin{tabular}{|c|c|c|c|}
\hline \multirow{2}{*}{$\begin{array}{c}\text { Tk. Pengetahuan } \\
\text { PHBS }\end{array}$} & \multicolumn{2}{|c|}{ Perilaku CTPS } & \multirow[b]{2}{*}{ Pvalue } \\
\hline & $\begin{array}{c}\text { Baik } \\
\text { N (\%) }\end{array}$ & $\begin{array}{c}\text { Kurang } \\
\text { N (\%) }\end{array}$ & \\
\hline $\begin{array}{c}\text { Baik } \\
\text { Kurang }\end{array}$ & $\begin{array}{l}49(90,7 \%) \\
20(48,8 \%)\end{array}$ & $\begin{array}{l}5(9,3 \%) \\
21(51,2)\end{array}$ & 0,000 \\
\hline
\end{tabular}

Tabel 7 menunjukkan bahwa responden dengan pengetahuan PHBS baik dan perilaku mencuci tangan baik sebanyak 49 orang (90,7\%), sedangkan responden dengan pengetahuan PHBS kurang dan perilaku mencuci tangan yang kurang sebanyak 21 orang $(51,2 \%)$ responden. Terdapat hubungan antara tingkat pengetahuan PHBS dengan perilaku CTPS yang ditunjukkan $p$ value $<0,05$ $(0,000)$. 
Tabel 8. Hubungan tingkat pengetahuan PHBS dengan perilaku pemberian ASI eksklusif pada warga di bantaran Sungai Kahayan daerah kerja Puskesmas Pahandut Palangka Raya tahun 2016.

\begin{tabular}{|c|c|c|c|}
\hline \multirow[b]{2}{*}{$\begin{array}{c}\text { Tingkat Pengetahuan } \\
\text { PHBS }\end{array}$} & \multicolumn{2}{|c|}{ Perilaku Pemberian ASI } & \multirow[b]{2}{*}{ Pvalue } \\
\hline & $\begin{array}{c}\text { Eksklusif } \\
\mathrm{N}(\%) \\
\end{array}$ & $\begin{array}{c}\text { Non Eksklusif } \\
\mathrm{N}(\%)\end{array}$ & \\
\hline $\begin{array}{c}\text { Baik } \\
\text { Kurang }\end{array}$ & $\begin{array}{l}40(74,1 \%) \\
13(31,7 \%)\end{array}$ & $\begin{array}{l}14(25,9 \%) \\
28(68,3 \%)\end{array}$ & 0,000 \\
\hline
\end{tabular}

Tabel 8 menunjukkan bahwa responden yang memiliki tingkat pengetahuan PHBS tatanan rumah tangga baik dan memberi ASI eksklusif sebanyak 40 orang $(74,1 \%)$. Responden yang memiliki tingkat pengetahuan PHBS tatanan rumah tangga kurang dan tidak memberikan ASI eksklusif sebanyak $28(68,3 \%)$ orang. Terdapat hubungan tingkat pengetahuan PHBS dengan perilaku memberi ASI eksklusif yang ditunjukkan $p$ value $<0,05(0,000)$.

\subsection{Pembahasan}

Karakteristik usia responden pada penelitian dikelompokkan berdasarkan kategori usia, didapatkan hasil kategori usia terbanyak yaitu usia 26-35 tahun sebanyak 34 orang $(35,8 \%)$ yang termasuk dalam kategori usia dewasa awal. Daya tangkap dan pola pikir seseorang dipengaruhi oleh usia. Daya tangkap dan pola pikir semakin bertambah usia akan semakin berkembang pula sehingga pengetahuan yang diperolehnya semakin membaik. Usia dewasa awal adalah usia ketika seseorang biasanya memiliki kematangan kognitif dalam puncak terbaik. Seseorang akan lebih mudah memahami sesuatu serta kemampuan produktivitas sangat baik, tetapi kemampuan kognitif seseorang berbeda. Kognitif dipengaruhi oleh lingkungan, emosional, sosiologis, kekuatan fisik, dan kemampuan menerima (Hapsari 2010; Notoatmodjo 2010).

Karakteristik responden pada penelitian berdasarkan pendidikan didapatkan hasil responden dengan pendidikan terakhir terbanyak yaitu SD sebanyak 45 orang $(47,4 \%)$. Pendidikan mendorong seseorang untuk ingin tahu, dan mencari pengalaman sehingga informasi yang didapat menjadi pengetahuan. Pendidikan dapat mempengaruhi perilaku kesehatan seseorang. Tingkat pendidikan seseorang berpengaruh terhadap kemampuan berpikir (Hapsari 2010). Pendidikan berpengaruh terhadap pengetahuan seseorang yang akan membentuk sikap dan perilaku sesuai dengan pengetahuannya (Notoatmodjo 2010).

Pengetahuan diperoleh dari hasil tahu dan terjadi setelah penginderaan terhadap suatu obyek tertentu dilakukan oleh seseorang. Melalui panca indera manusia melakukan penginderaan, yaitu indera penglihatan, pendengaran, penciuman, rasa dan raba. Melalui mata dan telinga manusia memperoleh sebagian besar pengetahuan. Semakin tinggi pengetahuan seseorang maka 
penerapan perilaku kesehatan dalam kehidupan sehari-hari akan lebih baik (Notoatmodjo 2012).

Dari hasil penelitian diketahui perilaku menggunakan jamban sehat warga di bantaran Sungai Kahayan wilayah kerja Puskesmas Pahandut Palangka Raya dapat dikategorikan perilaku baik yaitu sebanyak 67 orang (70,5\%).

Perilaku manusia merupakan aktivitas yang berasal dari manusia itu sendiri. Perilaku juga bermakna sebagai aktivitas manusia yang terjadi disebabkan oleh stimulus dan respons yang teramati secara langsung maupun tidak langsung. Perilaku kesehatan diartikan sebagai suatu respon individu (organisme) terhadap rangsangan (stimulus) yang berhubungan dengan kesehatan, meliputi sakit dan penyakit, makanan, sistem pelayanan kesehatan serta lingkungan (Notoatmodjo 2005). Suatu perilaku akan terwujud diawali dengan adanya pengalaman-pengalaman beserta faktor lingkungan fisik atau non fisik, selanjutnya hal tersebut setelah diketahui akan dipersepsikan, diyakini sehingga tumbuh motivasi serta niat untuk melakukan tindakan. (Ibrahim et al. 2012).

Berdasarkan Hasil analisis Chi Square dalam penelitian ini didapatkan $p$ value 0,000 $(<0,05)$. Hal tersebut menunjukkan bahwa ada hubungan yang signifikan antara tingkat pengetahuan PHBS dengan perilaku menggunakan jamban sehat pada warga di bantaran Sungai Kahayan wilayah kerja Puskesmas Pahandut Palangka Raya. Hasil ini sesuai dengan yang dinyatakan dalam penelitian Ibrahim et al. (2012) bahwa pengetahuan adalah hal yang penting untuk diketahui dalam menggunakan jamban. Jika pengetahuan tentang penggunaan jamban seseorang itu baik maka perilaku menggunakan jamban juga akan baik. Penelitian ini menyatakan bahwa ada hubungan signifikan antara pengetahuan seseorang dengan perilaku menggunakan jamban sehat. Hal ini sejalan pula dengan Pebriani (2012) yang menyatakan bahwa ada hubungan yang bermakna antara tingkat pengetahuan dengan pemanfaatan jamban keluarga.

Responden dengan pengetahuan PHBS baik dan perilaku mencuci tangan baik sebanyak 49 orang (90,7\%). Hal ini menunjukkan sebagian besar responden berperilaku baik dalam mencuci tangan. Responden yang berperilaku kurang baik mencerminkan bahwa responden belum memahami dengan baik mengenai CTPS. Tindakan pencegahan penularan penyakit melalui tangan dapat dilakukan dengan CTPS, misalnya diare dan infeksi saluran nafas atas. Tingkat pendidikan, pengetahuan dan kemudahan mengakses media massa mempengaruhi perilaku cuci tangan. Kebiasaan CTPS merupakan perilaku hidup sehat. Air dan lap tangan yang digunakan akan mempengaruhi CTPS dengan betul jadi tidak hanya caranya saja yang betul. Perilaku CTPS dilakukan tidak hanya saat tangan tampak kotor, tapi disarankan juga pada saat menyiapkan makanan, sebelum 
makan, sebelum memberi makan pada anak, setelah buang air besar dan setelah membersihkan anak BAB atau BAK (Proverawati dan Rahmawati 2012). Kurangnya kebiasaan responden berperilaku hidup bersih dan sehat khususnya mencuci tangan disebabkan belum memahami pentingnya dan manfaat mencuci tangan pakai sabun dalam kehidupan sehari-hari (Notoatmodjo 2003).

Dari data yang telah diperoleh hasil perhitungan dengan uji Chi Square analisis hubungan kedua variabel diperoleh $p$ value $0,000(p<0,05)$ berarti $\mathrm{H} 0$ ditolak. Hal tersebut menunjukkan bahwa terdapat hubungan yang signifikan antara pengetahuan PHBS terhadap perilaku mencuci tangan pakai sabun pada ibu rumah tangga di bantaran Sungai Kahayan wilayah kerja Puskesmas Pahandut Palangka Raya. Penelitian ini juga didukung Green (1980) yang menjelaskan perilaku seseorang dilandasi oleh 3 faktor, yaitu: faktor predisposisi, faktor pendukung, dan faktor penguat. Faktor predisposisi mencakup pengetahuan, sikap, tingkat pendidikan dan sebagainya. Faktor pendukung meliputi ketersediaan sarana prasarana atau fasilitas seperti sarana air bersih, ketersediaan sarana untuk mencuci tangan, tempat pembuangan sampah dan sebagainya. Faktor penguat mencakup sikap dan perilaku para petugas kesehatan. Pengetahuan akan mendasari lama tidaknya suatu perilaku bertahan. Berdasarkan teori tersebut disimpulkan bahwa pengetahuan merupakan salah satu faktor predisposisi yang mempengaruhi perilaku seseorang (Pebriani 2012).

Hasil pada penelitian ini sesuai dengan yang dilakukan dalam penelitian Muflih (2014) di Posyandu Cokrogaten, Ngemplak 1, Sleman Yogyakarta, hasil analisis menyatakan ada hubungan antara pengetahuan ibu terhadap perilaku cuci tangan pakai sabun sebagai pencegahan diare pada balita yang signifikan (Muflih 2014). Penelitian ini juga sesuai dengan penelitian Zuraidah dan Elviani (2013) di Kota Lubuklinggau, Sumatera Selatan, menyimpulkan bahwa ada hubungan pengetahuan dengan perilaku mencuci tangan dengan benar.

Analisis Chi Square pemberian ASI eksklusif diperoleh $p$ value 0,000 $(<0,05)$, menunjukkan bahwa ada hubungan signifikan antara tingkat pengetahuan PHBS dengan Perilaku memberikan ASI eksklusif pada warga di bantaran Sungai Kahayan wilayah kerja Puskesmas Pahandut Palangka Raya. Hal tersebut sesuai penelitian Aprilia (2012) di Desa Harjobinangun, Kecamatan Grabag, Kabupaten Purworejo, diperoleh hasil pengaruh pengetahuan dengan pemberian ASI eksklusif ( $p=0,007)$, yang menjelaskan bahwa pemberian ASI eksklusif dipengaruhi oleh pengetahuan ibu. Besar kecilnya peluang Ibu memberikan ASI eksklusif dipengaruhi baik buruknya pengetahuan (Aprilia 2012). Hasil penelitian Harahap et al. (2015) di wilayah kerja Puskesmas Pangirkiran, Kecamatan Halongonan, Kabupaten Padang Lawas Utara menunjukkan bahwa ibu yang berpengetahuan baik memiliki kemungkinan 
sebesar 1,4 kali untuk memberikan ASI eksklusif pada bayinya dibandingkan ibu yang tidak berpengetahuan baik.

\section{KESIMPULAN DAN SARAN \\ 4.1. Kesimpulan}

Gambaran tingkat pengetahuan PHBS Warga di Bantaran Sungai Kahayan Wilayah Kerja Puskesmas Pahandut Palangka Raya berpengetahuan baik 54 (56,8\%). Gambaran PHBS (menggunakan jamban sehat, CTPS dan pemberian ASI eksklusif) warga di bantaran Sungai Kahayan wilayah kerja Puskesmas Pahandut Palangka Raya secara berturut-turut 67 (70,5\%), 53 (55,8\%), dan 53 (55,8\%). Terdapat hubungan antara tingkat pengetahuan PHBS dengan PHBS (menggunakan jamban sehat, CTPS dan pemberian ASI eksklusif) warga di Bantaran Sungai Kahayan wilayah kerja Puskesmas Pahandut Palangka Raya secara berturut-turut $0,00,0,00$, dan $0,00(<0,05)$.

\subsection{Saran}

Sebaiknya dilakukan penelitian lanjutan untuk melihat PHBS yang lain mengingat PHBS tatanan rumah tangga terdapat 10 indikator. Dilakukan penelitian yang cakupan wilayahnya lebih besar untuk melihat keberhasilan program PHBS seperti yang dicanangkan oleh pemerintah propinsi Kalimantan Tengah. Meningkatkan penyuluhan PHBS agar capaian sesuai dengan target Indonesia.

\section{DAFTAR PUSTAKA}

Aprilia G. 2012. Hubungan tingkat pengetahuan ibu tentang asi eksklusif dengan pemberian asi eksklusif di Desa Harjobinangun Purworejo. Jurnal Komunikasi Kesehatan 3(2):49-55.

[Dinkes] Dinas Kesehatan Provinsi Kalimantan Tengah. 2014. Profil kesehatan

Provinsi Kalimantan Tengah tahun 2014. Dinkes Provinsi Kalimantan

Tengah. Palangka Raya.

[Dinkes] Dinas Kesehatan Kota Palangka Raya. 2015. Profil kesehatan Kota Palangka Raya tahun 2014. Dinkes Kota Palangka Raya. Palangka Raya.

[EHRA] Environmental Health Risk Assessment. 2014. Laporan studi Environmental Health Risk Assessment (EHRA) Kota Palangka Raya [internet]. Tersedia di: http://ppsp.nawasis.info.

Green L. 1980. Health education planning a diagnostic approach. Mayfield Publishing Co. California.

Hapsari NR. 2010. Analisis faktor yang berhubungan dengan praktik ibu rumah tangga tentang perilaku hidup bersih dan sehat di Desa Tunggulsari, Kecamatan Brangsong, Kabupaten Kendal tahun 2010 [Skripsi]. Ilmu 
Kesehatan Masyarakat, Fakultas Ilmu Keolahragaan, Universitas Negeri Semarang. Semarang.

Harahap IF, Siagian A dan Tampubolon E. 2015 Pengaruh faktor predisposisi pendukung dan pendorong ibu terhadap pemberian ASI eksklusif di wilayah kerja Puskesmas Pangirkiran, Kecamatan Halongoan, Kabupaten Padang Lawas Utara. Jurnal Ilmiah Pannmed 10(2):153-158.

Ibrahim I, Nuraini D dan Ashar T. 2012. Faktor-faktor yang berhubungan dengan pemanfaatan jamban di desa Pintu Langit Jae Kecamatan Padangsidempuan Angkola Julu Tahun 2012. Jurnal Lingkungan dan Keselamatan Kerja 2(3):110.

[Kemenkes RI] Kementerian Kesehatan Republik Indonesia. 2010. Pedoman perilaku hidup bersih dan sehat. Kemenkes RI. Jakarta.

[Kemenkes RI] Kementerian Kesehatan Republik Indonesia. 2013. Riset kesehatan dasar. Kemenkes RI. Jakarta.

Muflih. 2014. Hubungan pengetahuan ibu terhadap perilaku cuci tangan pakai sabun (CTPS) sebagai pencegahan diare pada balita [Skripsi]. Ilmu Keperawatan, Universitas Respati. Yogyakarta.

Notoatmodjo S. 2003. Pendidikan dan perilaku kesehatan. Rineka Cipta. Jakarta. Notoatmodjo S. 2005. Promosi kesehatan teori dan aplikasi. Rineka Cipta. Jakarta. Notoatmodjo S. 2010 Ilmu perilaku kesehatan. Rineka Cipta. Jakarta.

Notoatmodjo S. 2012. Promosi kesehatan dan perilaku kesehatan. Rineka Cipta. Jakarta.

Pebriani IL. 2012. Faktor-faktor yang berhubungan dengan pemanfaatan jamban keluarga dalam program pamsimas di wilayah kerja Puskesmas Koto Tinggi Kabupaten Lima Puluh Kota Tahun 2012 [Skripsi]. Fakultas Kesehatan Masyarakat, Universitas Andalas. Padang.

Proverawati A dan Rahmawati E. 2012. Perilaku hidup bersih dan sehat (PHBS). Nuha Medika. Yogyakarta.

Purwaningrum E. 2015. Tingkat pengetahuan remaja tentang perilaku hidup bersih dan sehat (PHBS) pada siswa kelas 2 di SMA Purwodadi [Karya Tulis Ilmiah]. Stikes Kusuma Husada. Surakarta.

Zuraidah dan Elviani Y. 2013. Hubungan pengetahuan dan sikap dengan perilaku mencuci tangan dengan benar pada siswa kelas V SDIT An-Nida' Kota Lubuklinggau tahun 2013. Jurnal Kesehatan Keperawatan 1(1). 